\title{
TRUST, TRUTH AND TRUCE TRAPPED \\ IN HYBRIDITY OF MODERN INTER-STATE \\ CONFLICTS: AN EARLY ASSESSMENT \\ OF THE RUSSO-WESTERN PROXY WAR IN UKRAINE
}

\begin{abstract}
Russo-Western relations after the declared end of the Cold War, just as on the eve and in the middle of it, have been fraught with developments pointing towards the persisting distrust and disgust in one another's perceptions cast against the background of officially declared truce. Such a decades-long half-truth-balancing has gradually lost its flexibility and acceptability and culminated in what much of the current academic debate calls, since 2014, a "Russian-Ukrainian conflict", but what, in fact, presents an extension to the latent Russo-Western conflict that embarked upon the end of the Cold War - a "cold peace".

This article aims to reveal the origins, form and substance of the current Russian hybrid gambling in Ukraine by addressing the essential notions in international but also domestic politics - trust, truth, lies/deception, distrust, war and peace immensely trapped by politics of incremental hybridity and interpretivism.
\end{abstract}

\section{Key words}

hybridity, (dis)trust, peace, war, Russian-Western conflict, Ukraine

* Andriy Tyushka, lecturer in Eastern European and Russian Studies, Department of Political and Strategic Studies, Baltic Defence College in Tartu, Estonia; SPaSIO research project fellow at the Faculty of Political Science and International Studies, Nicolaus Copernicus University of Torun, Poland. The author writes here in a personal capacity and his views are not necessarily representative of the Baltic Defence College. e-mail: andriy. tyushka@baltdefcol.org 